\title{
Identification of QTLs and possible candidate genes conferring sheath blight resistance in rice (Oryza sativa L.)
}

\author{
Shailesh Yadav ${ }^{\text {* }}$, Ghanta Anuradha', Ravi Ranjan Kumar ${ }^{5}$, Lakshminaryana Reddy Vemireddy ${ }^{1}$, Ravuru Sudhakar ${ }^{2}$, \\ Krishnaveni Donempudi ${ }^{3}$, Durgarani Venkata ${ }^{1}$, Farzana Jabeen ${ }^{1}$, Yamini Kalinati Narasimhan ${ }^{1}$, Balram Marathi ${ }^{1,4}$ \\ and Ebrahimali Abubacker Siddiq ${ }^{1}$
}

\begin{abstract}
Sheath blight, caused by the pathogenic fungus Rhizoctonia solani Kühn, is one of the most devastating diseases in rice. Breeders have always faced challenges in acquiring reliable and absolute resistance to this disease in existing rice germplasm. In this context, 40 rice germplasm including eight wild, four landraces, twenty- six cultivated and two advanced breeding lines were screened utilizing the colonized bits of typha. Except Tetep and ARC10531 which expressed moderate level of resistance to the disease, none could be found to be authentically resistant. In order to map the quantitative trait loci (QTLs) governing the sheath blight resistance, two mapping populations $\left(F_{2}\right.$ and $\left.B C_{1} F_{2}\right)$ were developed from the cross BPT-5204/ARC10531. Utilizing composite interval mapping analysis, 9 QTLs mapped to five different chromosomes were identified with phenotypic variance ranging from 8.40 to $21.76 \%$. Two SSR markers namely RM336 and RM205 were found to be closely associated with the major QTLs qshb7.3 and qshb9.2 respectively and were attested as well in $\mathrm{BC}_{1} \mathrm{~F}_{2}$ population by bulk segregant analysis approach. A hypothetical $\beta$ 1-3 glucanase with other 31 candidate genes were identified in silico utilizing rice database RAP-DB within the identified QTL region qshb9.2. A detailed insight into these candidate genes will facilitate at molecular level the intricate nature of sheath blight, a step forward towards functional genomics.
\end{abstract}

Keywords: Rice; Sheath blight; QTL mapping; Bulk segregant analysis (BSA); Defense response genes

Sheath blight, caused by Rhizoctonia solani Kühn of the anastomosis group AG1- IA, is potentially a devastating disease of rice (Oryza sativa) in the temperate and tropical rice growing regions of the world (Teng et al. 1990). In recent years, the disease has assumed serious epiphytotic proportions causing earnest crop losses under intensive rice production systems characterized by abundant application of nitrogenous fertilizers, high planting density, and extensive adoption of high-yielding cultivars (Slaton et al. 2002).

Breeding for sheath blight (ShB) resistance has been a futile exercise so far, mainly because of lack of reliable stable sources of resistance in rice germplasm (Jia et al. 2009; Zuo et al. 2010; Srinivasachary and Savary 2011;

\footnotetext{
*Correspondence: shaileshagri9@gmail.com

'Institute of Biotechnology, Acharya N G Ranga Agricultural University, Hyderabad 500030, India

Full list of author information is available at the end of the article
}

Liu et al. 2013). Though rice literature is replete with reports on the occurrence of sources with varied levels of resistance have been found as in Teqing ( $\mathrm{Li}$ et al. 1995; Pinson et al. 2005), Jasmine 85 (Pan et al. 1999; Zou et al. 2000; Liu et al. 2009), Minghui63 (Han et al. 2002), Xiangzaoxian 19 (Che et al. 2003), WSS2 (Sato et al. 2004), Pecos (Sharma et al. 2009) and Tetep (Sha and Zhu, 1989; Channamallikarjuna et al. 2010) and wild rices $O$. rufipogon, O. nivara etc. (Ram et al. 2008; Eizenga et al. 2013). Intensive study of the resistance in such sources reveals it to be quantitative in nature controlled possibly by polygenes (Sha and Zhu 1989; Li et al. 1995; Pinson et al. 2005; Zuo et al. 2013 It is widely believed that quantitative nature of resistance could be the expedient for evolving varieties with durable/horizontal resistance (Young, 1996; Poland et al. 2009). Precise mechanism underlying the quantitative resistance as yet not well understood, could be attributed to the host plant defense 
system through PR proteins in response to attack by pathogen (Datta et al. 1999; Vanloon and Strien 1999). Over-expression of PR proteins, including chitinases (PR-3), $\beta-1,3-$ glucanases (PR-2), thaumatin like proteins (PR-5), and other plant or microbe derived antifungal proteins in transgenic plants is known to provide resistance to sheath blight (Lin et al. 1995 and Datta et al. 2001).

With the rapid development of molecular marker technology, there have been significant advances in mapping ShB resistance QTLs: To date, around $50 \mathrm{ShB}$ resistance quantitative trait loci (ShBR QTLs) have been mapped to all the 12 rice chromosomes (Jia et al. 2009; Zuo et al. 2010; Xu et al. 2011 and Wang et al. 2012). Several recent studies have explore the possible candidate genes viz. Chitinase, Glucanase, Glutathione S-Transferase and Kinase protein within the mapped QTL region may responsible for sheath blight resistance (Channamallikarjuna et al. 2010; Silva et al. 2012; Zuo et al. 2014). Though most of the ShBR QTLs identified so far are of only limited effects on ShB resistance, instances of some showing expected effect were not uncommon. For instance Zuo et al. (2007) reported introgression of the QTL, $q S B-11^{L E}$ and observed reduced grain loss by $10.71 \%$ in Lemont background under severe disease infestation in field trials. Pinson et al. (2005) predicted that $q S B-9^{T Q}$ and $q S B-3^{T Q}$ could possibly reduce the crop loss due to ShB by $15 \%$ when introduced into Lemont. Yin et al. (2010) and Wang et al. (2012) have found that pyramiding of diverse ShBR QTLs could help achieve higher levels of resistance to ShB. Thus, it is likely that the level of resistance to the disease could be raised by pyramiding diverse ShBR QTLs differing in their level of moderate resistance.

Keeping in view this possibility the present investigation was conducted to i) identify ShB resistance source(s), ii) establish their genetic diversity by molecular mapping of the QTLs associated with sheath blight resistance by using $\mathrm{F}_{2: 3}$, iii) validation of markers associated with sheath blight resistance in $\mathrm{BC}_{1} \mathrm{~F}_{2}$, iv) to identify the possible candidate genes in the QTL region by in silico analysis.

\section{Materials and methods}

\section{Plant material}

Forty rice germplasm including improved cultivars (26), wild (8), landraces (4) and advanced breeding lines (2) were screened to identify resistance sources for sheath blight disease. Of these, some genotypes were previously reported to be sources of resistance to the disease (Table 1).

Evaluation of rice germplasm for sheath blight resistance The screening for the disease reaction was carried out in Kharif 2011 at the Institute of Biotechnology, ANGRAU under the artificial epiphytotic conditions in a hot humid
Table 1 List of rice germplasm screened for Sheath Blight Resistance

\begin{tabular}{lll}
\hline Sr. no. & Genotype & Source \\
\hline Wild Accessions & \\
$\mathbf{1}$ & Oryza rufipogon AC100488 & DRR-Hyderabad \\
$\mathbf{2}$ & O. rufipogon AC 100368 & DRR-Hyderabad \\
$\mathbf{3}$ & O. rufipogon AC 100490 & DRR-Hyderabad \\
$\mathbf{4}$ & O. rufipogon AC100483 & DRR-Hyderabad \\
$\mathbf{5}$ & O. nivara AC100456 & DRR-Hyderabad \\
$\mathbf{6}$ & O. nivara AC 100396 & DRR-Hyderabad \\
$\mathbf{7}$ & O. nivara AC 100395 & DRR-Hyderabad \\
$\mathbf{8}$ & O. nivara AC 100110 & DRR-Hyderabad
\end{tabular}

Landraces

$\mathrm{N}-22$

NDUAT-Faizabad

10 Tetep

NRCPB- New Delhi

Moroberakan

DRR-Hyderabad

AAU-Assam

12

Cultivated

13

ARC 10531

ANGRAU-Hyderabad

OUAT-Odisha

DRR-Hyderabad

Swarnadhan

ANGRAU-Hyderabad

Kavya

IR-64

Lalnakandha

IRRI,Philippines

TNAU-Coimbatore

Naveen

CRRI-Cuttack

MTU1061

Vandana

Pusa basmati

ANGRAU-Hyderabad

ANGRAU-Hyderabad

IARI-New Delhi

MTU1001

ANGRAU-Hyderabad

Sonasali

BPT-5204

Jaya

DRR-Hyderabad

ANGRAU-Hyderabad

DRR-Hyderabad

TNAU-Coimbatore

TKM-6

Nilagiri

Jyothi

WGL-32100

OUAT-Odisha

KAU-Kerala

ANGRAU-Hyderabad

Ghanteswari

ANGRAU-Hyderabad

MTU-1010

ANGRAU-Hyderabad

WGL-14

ANGRAU-Hyderabad

Chandan

CRRI-Cuttack

Surekha

Khandagiri

ANGRAU-Hyderabad

OUAT-Odisha

JGL-3844

Jaganath

ANGRAU-Hyderabad

TNAU-Coimbatore

Advanced Breeding Lines

$\begin{array}{ll}39 & \text { RIL-45 } \\ 40 & \text { RIL-140 }\end{array}$

NRCPB- New Delhi NRCPB- New Delhi 
chamber. The material was sown in 3 replications in separate pots and maintained in the humid chamber at optimum humidity $(90 \%)$ and temperature $\left(28-30^{\circ} \mathrm{C}\right)$, which are very favorable for the disease development.

\section{Multiplication of the pathogen}

In the present study, the most virulent local Rajendranagar isolate of rice sheath blight pathogen $R$. solani AG 1-IA (Wamishe et al. 2007) obtained from the Division of Plant Pathology, Directorate of Rice Research, Hyderabad and utilized used for disease screening.

Before the inoculation, the fungus was cultured in potato dextrose agar (PDA) medium at $28^{\circ} \mathrm{C}$ for 3-4 days, followed by transferring of disc of medium with mycelia for multiplication. The inoculum of the virulent isolate was multiplied by following the procedure described by Bhaktavatsalam et al. (1978). Typha stem bits of $4-5 \mathrm{~cm}$ long were washed exhaustively and soaked in typha medium for 5 minutes. Subsequently, they were filled loosely to $1 / 3$ volume of $500 \mathrm{ml}$ conical flask and autoclaved for 20 minutes each for two consecutive days. The sterilized flasks with typha were inoculated with $5 \mathrm{~mm}$ diameter disk of actively growing mycelium of $R$. solani AG1-IA and incubated for one week at $28 \pm 2^{\circ} \mathrm{C}$. Then colonized typha stem bits so developed were utilized as inoculum.

\section{Pathogen inoculation and disease scoring}

Plants at maximum tillering stage were inoculated with $R$. solani by placing the typha pieces infected with $R$. solani between tillers in the central region of rice hills 5-10 $\mathrm{cm}$ above waterline. So inoculated plants were then kept in a humid chamber made of clear plastic maintained at $28^{\circ} \mathrm{C}$ under 14-hr day light for 2 weeks to allow disease development in the greenhouse. Humidity was maintained between 80 and $90 \%$ from the time of inoculation for disease evaluation. Inoculated plants were scored for disease reaction as percentage relative lesion height (RLH\%) 14 days after inoculation as under:

$$
\mathrm{RLH} \%=\frac{\text { Lesion height }(\mathrm{cm})}{\text { Plant height }(\mathrm{cm})} \times 100
$$

The scoring was done on 0-9 scale of Standard Evaluation System (SES) for rice (IRRI, 2002) detailed in Additional file 1: Table S1.

\section{Experimental population}

In the present study, ARC10531 and Tetep were identified as moderately resistant to sheath blight among the 40 rice germplasm screened. Tetep is a known source for moderate resistance to the disease and QTLs relating to resistance has already been reported by Channamallikarjuna et al. (2010). Hence, the present study was confined to
ARC 10531 for development of mapping population and mapping of QTLs conferring resistance.

One mapping population consisted of $210 \mathrm{~F}_{2: 3}$ progeny lines derived from the cross between the susceptible BPT-5204 and moderately resistant ARC10531. The susceptible parent BPT-5204 is the late -maturing, fine grain, semi-dwarf and high yielding variety but highly susceptible to $R$. solani. The resistant parent ARC 10531 is a late-maturing, bold grain and tall land race from Assam with moderate resistance to ShB. The other mapping population $\left(\mathrm{BC}_{1} \mathrm{~F}_{2}\right)$ comprising 150 plants derived from the same cross (BPT-5204/ARC10531) planted in the green house at IBT (ANGRAU) were used to validate the markers linked to sheath blight resistance QTLs.

\section{Phenotyping of $\mathrm{F}_{2: 3}$ and $\mathrm{BC}_{1} \mathrm{~F}_{2}$ population}

The 210 plants of $\mathrm{F}_{2: 3}$ and 150 of $\mathrm{BC}_{1} \mathrm{~F}_{2}$ population derived from the cross (BPT-5204/ARC10531) were grown in pots as well as under soil bed conditions. The plants were inoculated with $R$. solani multiplied in typha bits and disease reaction for the disease was recorded as per the Standard Evaluation System described earlier.

\section{Bulk segregant analysis}

Bulk Segregant Analysis (BSA) is as an efficient strategy for identifying the DNA markers linked to the gene(s) or genomic regions of interest (Michelmore et al. 1991). By making DNA bulks, all loci are randomized, except for the region containing the gene of interest. In this approach, the markers are screened across the parents and two bulks. Polymorphic markers may represent markers that are linked to the gene or QTL of interest (Collard et al. 2005). DNA bulks of plants showing resistant reaction and of those found susceptible were prepared from $\mathrm{BC}_{1} \mathrm{~F}_{2}$ population. This was done by pooling aliquots, containing equivalent amounts of DNA approximately, $50 \mathrm{ng} / \mu \mathrm{l}$ from each of ten highly resistant and ten highly susceptible plants of the $\mathrm{BC}_{1} \mathrm{~F}_{2}$ generation predicated on phenotypic observations. Seventy polymorphic SSR primers were utilized for screening the parents and the two bulk DNA samples.

\section{Construction of molecular linkage map}

The total genomic DNA was extracted of young leaves from each of the $F_{2}$ plants along with those of the two parental lines - BPT5204 and ARC10531as per the method described by Murray and Thompson (1980). The concentration of the DNA was detected with the aid of ultraviolet spectrophotometer. The DNA quality was judged by running on $0.8 \%$ agarose gel electrophoresis stained with ethidium bromide $(\mathrm{EtBr})(10 \mathrm{mg} / \mathrm{ml})$ using $1 \times$ TAE buffer at constant voltage $70 \mathrm{~V}$ for $30 \mathrm{mi}-$ nutes and visualized under UV light. The DNA was amplified through PCR using reaction mixture (total 
volume $10 \mu \mathrm{l}$ ), containing $20 \mathrm{ng}$ template DNA, $10 \mathrm{mM}$ Tris- $\mathrm{HCl}, 50 \mathrm{mM} \mathrm{KCl}, 2.5 \mathrm{mM} \mathrm{MgCl} 2,10 \mathrm{mM}$ dNTPs, 5 pmol each primers and $1.0 \mathrm{U}$ Taq DNA polymerase. The PCR reaction was performed as DNA denaturation at $94^{\circ} \mathrm{C}$ for 4 minutes followed by 35 cycles $\left(94^{\circ} \mathrm{C}\right.$ for 1 minutes, $55^{\circ} \mathrm{C}$ for 1 minutes, $72^{\circ} \mathrm{C}$ for $1 \mathrm{mi}$ nutes) and final extension step (at $72^{\circ} \mathrm{C}$ for 10 minutes). The PCR product was subjected to electrophoresis on $4 \%$ metaphor agarose. The DNA fragments were then visualized under UV-transilluminator and documented using a gel documentation system (BIO-RAD Gel Doc ${ }^{\mathrm{TM}}$ XR, USA).

Identification of sufficient number of markers revealing polymorphism among the parental lines is a prerequisite for the construction of a genetic linkage map. In this study, parental polymorphism survey was carried out between the two parents (ARC10531 and BPT-5204) using a total of 500 SSR markers spanning all the 12 chromosomes of rice (http://www.gramene.org/). The list of polymorphic markers with their details is depicted in Additional file 1: Table S2.

Seventy polymorphic markers were used for genotyping of the $210 \mathrm{~F}_{2}$ individuals along with parental lines. A linkage map was constructed by using MAPMAKER 3.0 (Cambridge, MA, USA; Lander et al. 1987). The map distances were calculated based on Kosambi's function (Kosambi, 1944).

\section{QTL mapping}

Identification of QTLs for ShB resistance was completed using the software QTL cartographer v. 2.5 (Wang et al. 2004 http://statgen.ncsu.edu/qtlcart/WQTLCart.htm). To identify additional QTLs that may have been masked by the major QTLs, composite interval mapping (CIM) method was employed. Genome-wide threshold values $(\alpha=0.05)$ were used to detect putative QTLs on the basis of the results of 1000 permutations (Churchill and Doerge 1994). The likelihood-ratio (LR) test statistic used was $-2 \ln (\mathrm{L} 0 / \mathrm{L} 1)$, where $\mathrm{L} 0 / \mathrm{L} 1$ is the ratio of the likelihood under the null hypothesis (there is no QTL in the interval) and the alternative hypothesis (there is a QTL in the interval). The presence of a putative QTL was declared if the LOD threshold was larger than 3.0 (Basten et al. 2002). The QTLs were deemed to exist only at positions where an LOD score exceeded the corresponding significant threshold. Estimation of the position, genetic effects, and percentage of phenotypic variation of the QTLs were done at the significant LOD peak in the region under consideration. The proportion of phenotypic variation explained by each QTL was calculated as $\mathrm{R}^{2}$ value, and the degree of dominance of a QTL was estimated as the ratio of dominance effect to additive effect.

\section{Results and discussion}

\section{Screening of rice germplasm for sheath blight resistance}

Among the 40 rice germplasm comprising wild accessions, land race, improved cultivars and advanced breeding lines (RIL-45 and RIL140) screened for sheath blight resistance, only two genotypes viz Tetep and ARC10531 found to in the range of $21-30 \%$ denoting them to be of moderate resistance (Table 2). Tetep is a well reported source of resistance to sheath blight and several QTLs have already been mapped by number of researchers. The land race ARC 10531 identified in the present study was observed with equal levels of resistance as that of Tetep, could be used as an alternate source for ShB resistance (Figures 1 and 2). The information generated in the present study would be valuable in future rice breeding programmes aimed at improving resistance to sheath blight.

Several researchers have attempted in the past to identify sources of resistance to ShB by screening a large number of wild species, landraces, local and improved cultivars, advanced breeding lines using different screening techniques (Srinivasachary and Savary 2011). They broadly included use of colonized typha bits (Bhaktavatsalam et al. 1978), a toothpicks infected with $R$. solani (Zou et al. 2000), broadcasting of inoculum on rice plants ( $\mathrm{Li}$ et al. 1995; Savary et al. 1995; Singha and Borah 2000 and Han et al. 2002), infected rice grain-hull mixtures (Pan et al. 1999; Willocquet et al. 2000), detached leaf technique (Prasad and Eizenga, 2008) and micro-chamber method (Jia et al. 2009) under controlled greenhouse conditions. In comparison with field $\mathrm{ShB}$ evaluation, the micro-chamber and mist-chamber assays were simple, precise and more reliable assays methods in tagging ShB resistance (Liu et al. 2009; Jia et al. 2009). In the present study controlled chamber method was adopted by keeping the potted plants inoculated with typha bits under greenhouse condition, maintained at optimum humidity $(90 \%)$ and temperature $\left(28-30^{\circ} \mathrm{C}\right)$ for disease development.

As for disease development and expression, earlier reports suggest plant height to be related to disease severity (Sharma et al. 2009; Liu et al. 2014) reveal relatively tall statured plants favor disease escape delaying the spread of the pathogen to canopy. In the present study, ARC 10531 and Tetep exhibited low RLH\% possibly due to a well-developed mechanism against sheath blight disease as well as their tall stature nature which delays the spread of the pathogen to the canopy in these moderately resistant line. The statement cannot be generalized as in the present study other varieties and wild accessions tall in stature expressed susceptibility towards ShB disease. Pace of disease development need not be due to plant height alone. Possibly there may be other factors associated with the resistance gene warranting more detailed study of such an association. Channamallikarjuna et al. 2010 similarly viewed that sheath blight resistance 
Table 2 Grouping of rice genotypes based on their reactions against the fungus $R$. solani, AG1-IA

\begin{tabular}{|c|c|c|c|}
\hline Grade & $\begin{array}{l}\text { Relative lesion } \\
\text { height (\%) }\end{array}$ & Reaction & Genotypes \\
\hline 0 & 0 & Immune & Nil \\
\hline 1 & $1-20$ & Resistant & Nil \\
\hline 3 & $21-30$ & $\begin{array}{l}\text { Moderately } \\
\text { resistant }\end{array}$ & Tetep, ARC-10531 \\
\hline 5 & $31-45$ & $\begin{array}{l}\text { Moderately } \\
\text { susceptible }\end{array}$ & RIL-140 of cross HP2216x Tetep, Swarnadhan, MTU 1061, Kavya, Naveen, Oryza rufipogon AC 100490, \\
\hline 7 & $46-65$ & Susceptible & $\begin{array}{l}\text { Rajeswari, Moroberakan, Vandana, Lalnakandha, MTU 1001, Oryza nivara AC100395, AC100396, Oryza } \\
\text { rufipogon AC100488, Sonasali and Pusa Basmati, }\end{array}$ \\
\hline 9 & $66-100$ & $\begin{array}{l}\text { Highly } \\
\text { susceptible }\end{array}$ & $\begin{array}{l}\text { TKM-6, Nilagiri, Jyothi, WGL32100, Chandan,N-22,Ghanteswari, MTU-1010, Jaya, Jaganath, WGL14, } \\
\text { Surekha, JGL-3844,IR-64, Khandagiri, Oryza nivara AC100456, AC1001100ryza rufipogon AC100483 and } \\
\text { AC100368, RIL-45 of cross HP2216x Tetep, BPT-5204, }\end{array}$ \\
\hline
\end{tabular}

quantified in Tetep might be due to the molecular mechanisms involved in host- pathogen interaction and not due to any morphological adaptation to evade disease. The heading date is also associated significantly with $\mathrm{ShB}$ resistance and the varieties with later maturing are generally more resistant to ShB (Zuo et al. 2010; Srinivasachary and Savary 2011).

The present study though could not succeed in finding a strong source of resistance to sheath blight, assumes importance in identifying additional source of moderate resistance to the diseases in ARC10531 besides the already known source Tetep. If they are found to be of diverse genetics, they would prove a base for pyramiding them and expect enhanced level of resistance.

\section{Phenotype distribution analysis}

The $F_{2: 3}$ progenies exhibited significant phenotypic variance for the disease reaction (Figure 3). Frequency distribution of $\mathrm{F}_{2: 3}$ was continuous and fitted into normal distribution as expected from a quantitative trait (Figure 4).
The population appeared to be skewed towards the susceptible range of $40-50 \%$ and the percentage relative lesion height ranging between $21 \%$ and $75 \%$ with the mean value of $31.51 \%$. Similar to the $\mathrm{F}_{2: 3}$ population, the frequency distribution of the $\mathrm{BC}_{1} \mathrm{~F}_{2}$ population was also skewed towards susceptibility (Figure 5). Broadly the findings were in agreement with those of Sharma et al. (2009), who also observed the frequency distribution to be continuous showing skewness towards susceptibility.

\section{Linkage map construction and QTL analysis}

Of the 500 markers screened on the parental genotypes (BPT-5204 and ARC10531), 70 SSR markers were found polymorphic. The percent polymorphism between BPT5204 and ARC10531 was low. Low level of parental polymorphism can be attributed to the narrow genetic variation between the parents as both were indica ecotypes and adapted to grow in the same rice ecosystem. Several line of evidence are in support which also indicate low level of polymorphism between the parents in

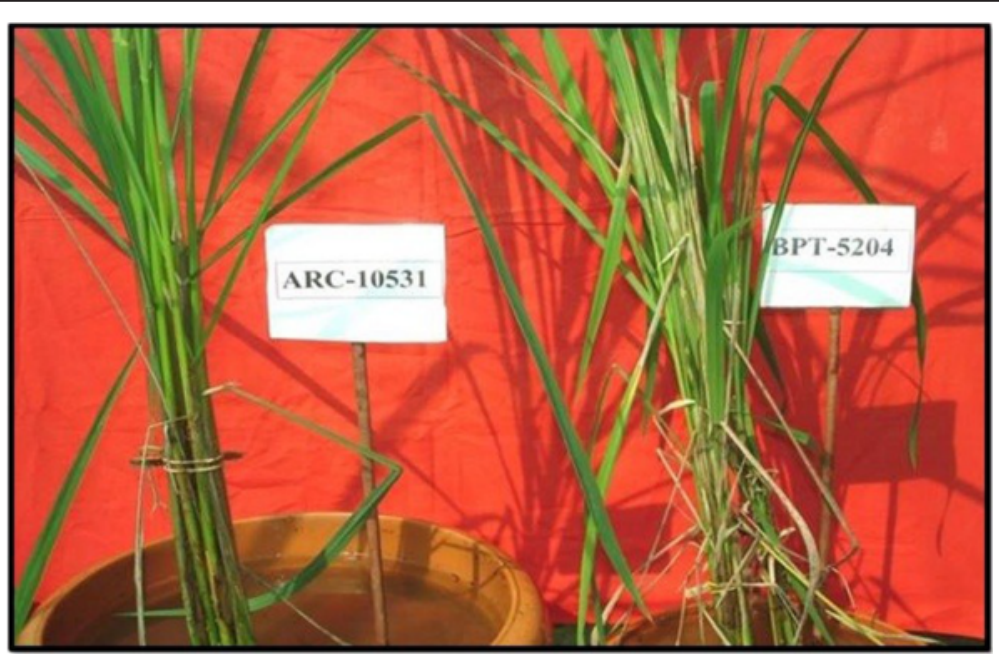

Figure 1 Disease reaction of ARC 10531 and BPT-5204 (observations were recorded after 14 days of inoculation). 


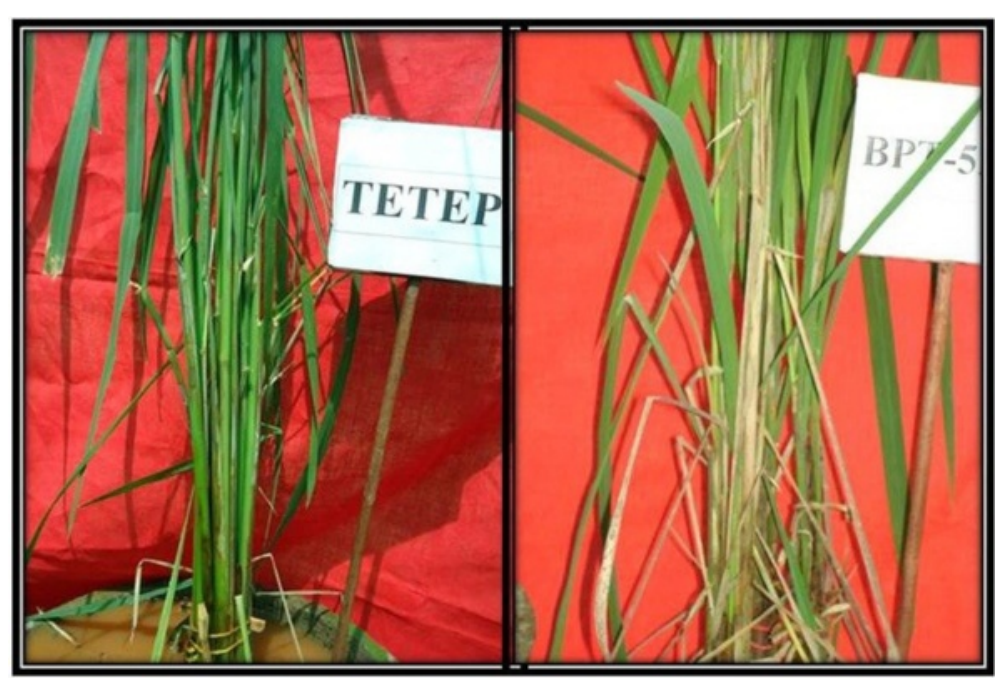

Figure 2 Disease reaction of Tetep and BPT-5204 (observations were recorded after 14 days of inoculation).

the intra-sub-specific (Ali et al. 2000; Subashri et al. 2009; Gomez et al. 2010) and even in inter-sub-specific crosses of rice (McCouch et al. 1988; Price and Tomos, 1997). The polymorphic markers were used for genotyping of the $\mathrm{F}_{2: 3}$ mapping population. Majority of the loci followed Mendelian ratio i.e., 1:2:1 except ten markers. Based on the $F_{2}$ population, a genetic linkage map including 60 markers evenly distributed over all the 12 chromosomes was constructed and used to identify QTLs for rice sheath blight resistance. Using CIM analysis, a total of 9 QTLs were identified on chromosomes
$1,6,7,8$ and 9 (Table 3). The 3 QTLs were identified on each of the chromosomes 7 and 9. Some of the QTLs identified in the present study have also been reported in previous studies, suggesting the existence of some conserved chromosomal regions linked with ShB resistance (Tan et al. 2005; Liu et al. 2009; Wang et al. 2012; Shiobara et al. 2013; Zuo et al. 2014). However, some new ShB QTLs were also identified on chromosome 1, 7 and 8 (Figure 6) in addition to those earlier reported.

On chromosome 1, the QTLs qshb1.1 was found linked to the markers RM151 and RM12253 respectively
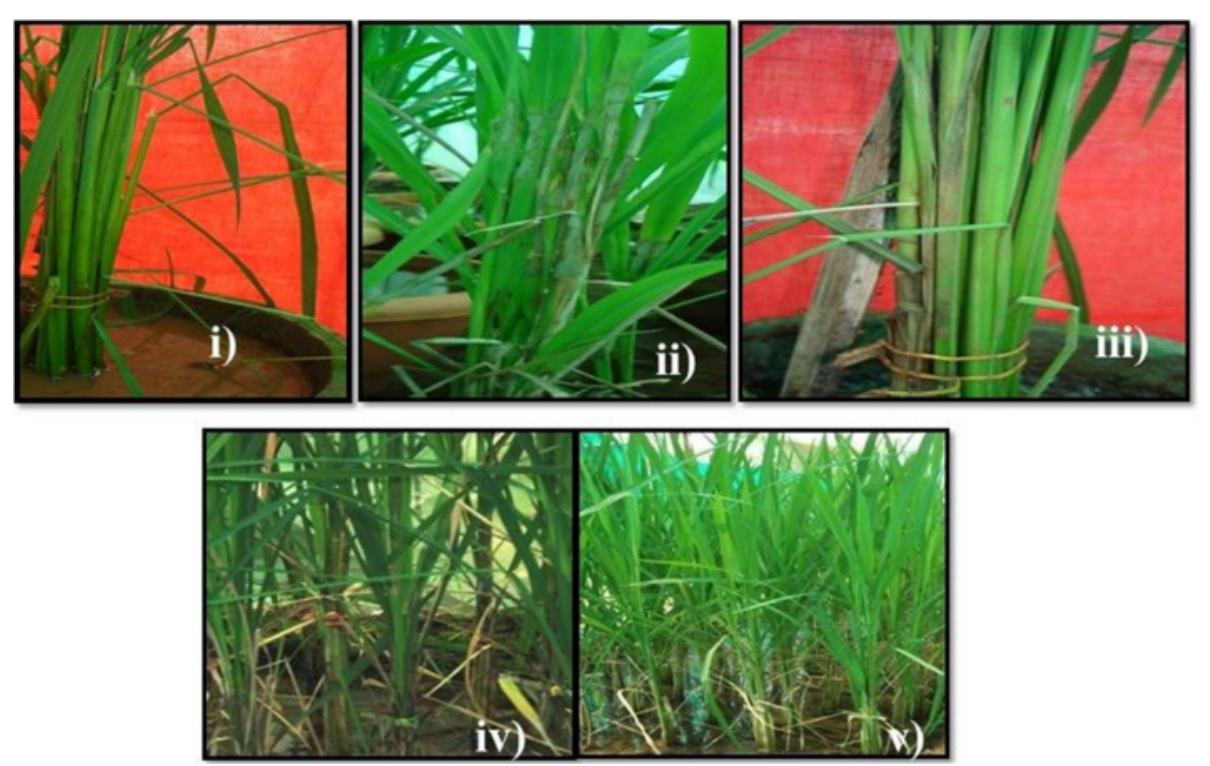

Figure 3 Disease reaction of i) ARC-10531, ii) BPT-5204, iii) $F_{1}$, iv and $\mathbf{v}$ ) individuals of mapping population $F_{2: 3}$ showing moderately resistant and susceptible reaction. 


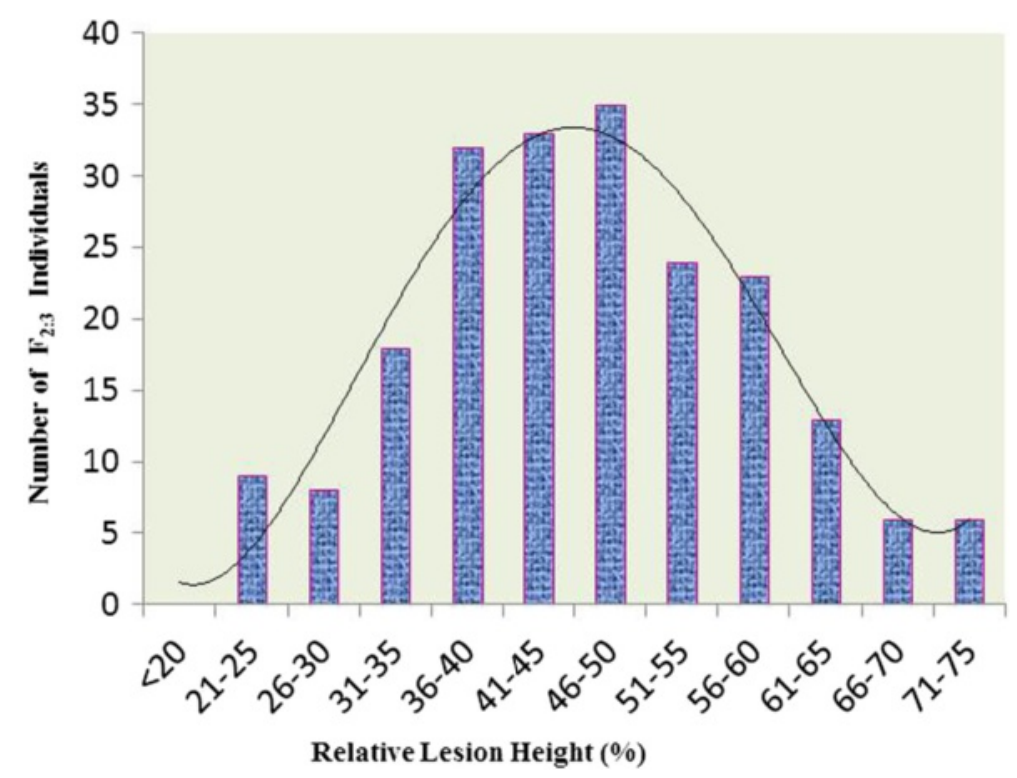

Figure 4 Frequency distribution curve of Sheath Blight disease incidence among $210 \mathrm{~F}_{2: 3}$ individuals derived from the cross (BPT-5204 × ARC10531).

with phenotypic variance of $10.99 \%$ and $12.18 \%$, explaining involvement of additive gene action. Earlier workers too mapped ShB resistance to chromosome 1, but at locations different from the presently identified location (Liu et al. 2009; Jia et al. 2012). For ShB QTL on chromosome 6 (qshb6.1), the genomic region identified in the present study were same as the ones reported earlier by Zou et al. (2000) and Liu et al. (2009), but the peak markers were different. Thus, the markers linked to the ShB resistances QTLs on chromosome 1, 6 and 8 were different and reported for the first time. Likewise the QTL qshb8.1 was found at almost the same genomic region as that of the QTL reported by Li et al. (1995) and Channamallikarjuna et al. (2010).
On chromosome 7, three QTLS qshb7.1, qshb7.2, and $q$ shb7.3 were mapped and phenotypic variance of 21.76\% was observed for QTL qshb7.3 denoting strong additive gene action. Four studies detected QTLs for sheath blight around the chromosomal region of qshb7.3 (Pan et al. 1999; Zou et al. 2000; Kunihiro et al. 2002 and Liu et al. 2009).

Some of the chromosomal regions containing ShBR QTLs and its associated markers identified in present investigation were also reported earlier by different researchers. However, the genomic locations of these QTLs were observed to be different in different populations. These might be due to the use of different sources of resistance to sheath blight in different studies, varying

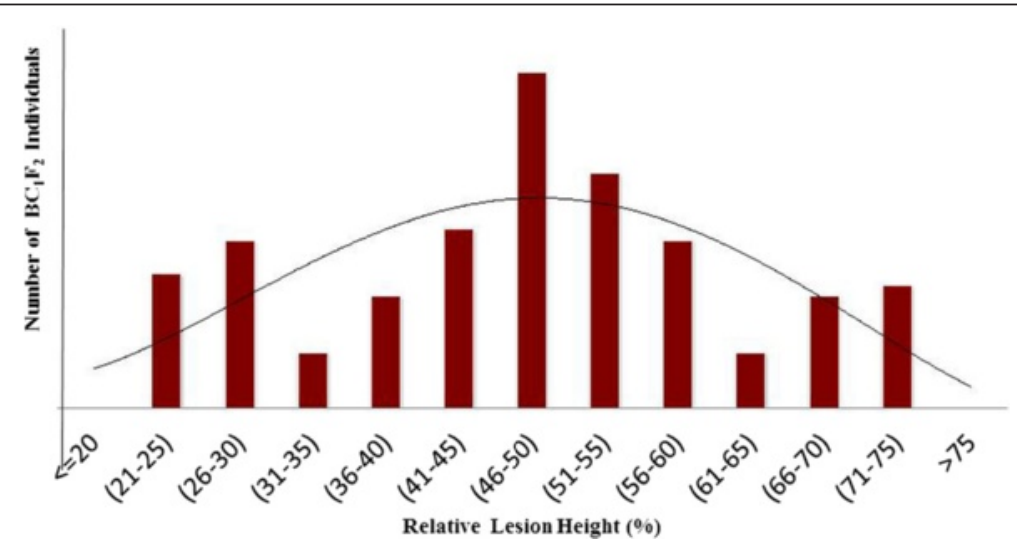

Figure 5 Frequency distribution curve of sheath blight disease incidence among 150 individuals of $\mathrm{BC}_{1} \mathrm{~F}_{2}$ population derived from the cross (BPT-5204 $\times$ ARC10531) 
Table 3 QTLs identified for Sheath Blight Resistance by Composite Interval Mapping (CIM)

\begin{tabular}{lllllllll}
\hline S.no & QTLs & Chr. & Marker & Marker Interval & LOD & \%R $^{\mathbf{2}}$ & Additive & Dominance \\
\hline $\mathbf{1}$ & qshb1.1 & 1 & RM151 & RM151-RM12253 & 10.7 & 10.99 & 13.9051 & -24.7665 \\
$\mathbf{2}$ & qshb6.1 & 6 & RM400 & RM400-RM253 & 4.43 & 13.25 & -9.0513 & 2.0605 \\
$\mathbf{3}$ & qshb7.1 & 7 & RM81 & RM81-RM6152 & 8.8 & 10.52 & -5.5132 & -6.0402 \\
$\mathbf{4}$ & qshb7.2 & 7 & RM10 & RM10-RM21693 & 6.7 & 9.72 & -3.0300 & -2.9706 \\
$\mathbf{5}$ & qshb7.3 & 7 & RM336 & RM336-RM427 & 4.12 & 21.76 & 2.8837 & -3.0868 \\
$\mathbf{6}$ & qshb8.1 & 8 & RM21792 & RM21792-RM310 & 4.2 & 10.52 & -3.6675 & -3.7066 \\
$\mathbf{7}$ & qshb9.1 & 9 & RM257 & RM257-RM242 & 5.9 & 8.40 & -3.1244 & -2.1194 \\
$\mathbf{8}$ & qshb9.2 & 9 & RM205 & RM205-RM105 & 7.0 & 19.81 & 3.7999 & -4.2493 \\
$\mathbf{9}$ & qshb9.3 & 9 & RM24260 & RM24260-RM 3744 & 3.5 & 12.58 & -3.2724 & -2.4682 \\
\hline
\end{tabular}

methodologies of assessing sheath blight resistance, or the use of different marker densities as earlier expressed by Channamallikarjuna et al. (2010).

A QTL region qshb7.3 identified on chromosome 7 associated with marker RM336 was in agreement with the previously reported result of Channamallikarjuna et al. (2010) with different genomic location. The alleles explained $21.76 \%$ of total phenotypic variance in contrast with the report of Channamallikarjuna et al. (2010) depicting only $10.02 \%$ for this QTL. This might be due to interaction of favorable alleles in this source (ARC10531) of resistance. The QTL region qshb7.3 associated with same peak marker RM336 in both the studies represents the stability of the QTL for sheath blight resistance.

The major QTL qshb9.2 identified on chromosome 9 associated with marker RM205 was earlier reported by Tan et al. (2005) in $F_{2}$ population derived from a Lemont/ Teqing. The QTL location, associated marker and phenotypic variance identified in their study was quite similar to that observed in our study. The QTL qshb9.2 identified in this study not only helped in validation of QTL once again, but also provided an alternate source of resistance for introgression of the QTL into any elite variety. This consistent QTL region $q$ shb-9 for sheath blight resistance on chromosome 9 has been verified by various independent researches ( $\mathrm{Li}$ et al. 1995; Tan et al. 2005; Pinson et al. 2005; Liu et al. 2009; Yin et al. 2010; Zuo et al. 2014) and in the present study, indicating its authenticity and potentially breeding value in practice. These may be candidate regions to explore in $\mathrm{ShB}$ resistance breeding programme. The major ShB-QTLs qshb7.3and qshb9.2 identified in the present study, as a favorable QTL can be readily transferred using MAS into elite cultivars to strengthen their resistance levels. In addition, we have identified other minor ShB QTLs, which can be used to develop new cultivars with improved resistance to this important disease.

Although the present findings are preliminary and QTL were identified under controlled condition, the validation of identified QTLs in other populations with

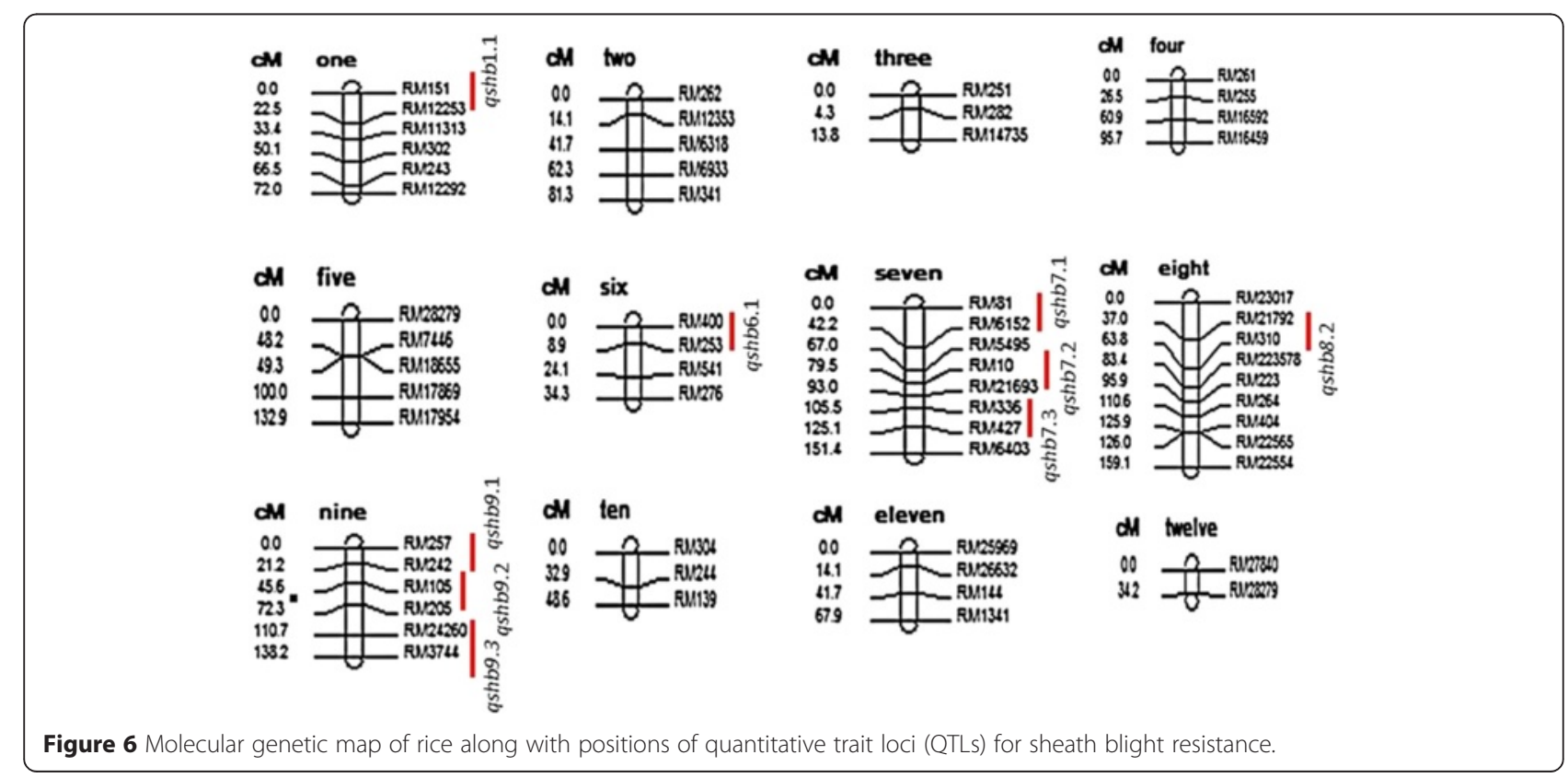




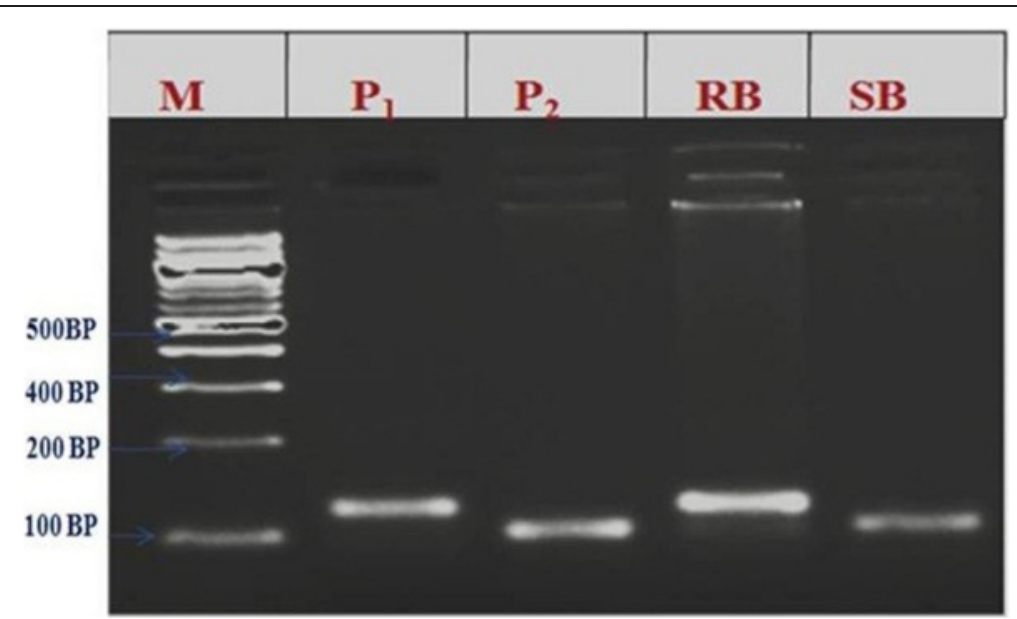

Figure 7 Results of bulk segregant analysis of $\mathrm{BC}_{1} \mathrm{~F}_{2}$ population with SSR marker RM 205 M-100 bp ladder; $\mathrm{P}_{1}-\mathrm{ARC} 10531 ; \mathrm{P}_{2}-\mathrm{BPT}-5204$; RB-Resistance bulk; SB-Susceptible bulk.

adequate size and number of markers tested across multiple environments would add additional landmark in regards to identify resistance genes against sheath blight.

\section{Confirmation of linked microsatellite markers associated with sheath blight resistance in rice}

The two SSR markers (RM336 and RM205) associated with major QTL qshb7.3 and qshb9.2 were reconfirmed in $\mathrm{BC}_{1} \mathrm{~F}_{2}$ population using bulk segregant analysis approach. The DNA from 10 extreme resistant and 10 extreme susceptible plants were pooled separately and amplified along with both the parents using the same SSR markers RM336 and RM205 (Figures 7 and 8). The alleles were showing co-segregation among the parents ARC10531, BPT-5204 and pooled DNA of resistant bulk and susceptible bulk with SSR markers RM336 and RM205.

Channamallikarjuna et al. (2010) utilized an $\mathrm{F}_{2}$ population derived from resistant parent Tetep, to confirm the linked marker associated with sheath blight QTL identified in RIL population. They validated the marker RM224 linked to major QTL, qSBR11-1 identified during their earlier study with RILs of same cross. In the present study, the two microsatellite markers RM336 and RM205 associated with major QTLs, qshb7.3 and qshb9.2 were reconfirmed in the $\mathrm{BC}_{1} \mathrm{~F}_{2}$ population by using BSA approach. The evaluation of stable line phenotypically at the ShB hot spot location to study the stability of the identified major QTL could speed up the process of authenticating markers

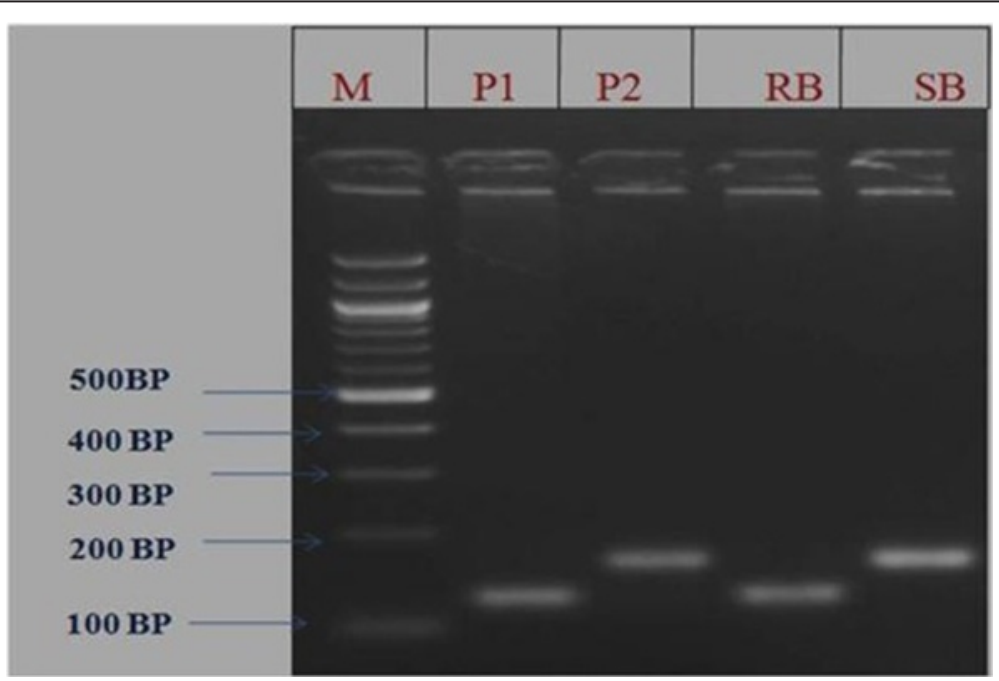

Figure 8 Results of bulk segregant analysis of $\mathrm{BC}_{1} \mathrm{~F}_{2}$ population with SSR marker RM 336 M-100 bp ladder; $\mathrm{P}_{1}-\mathrm{ARC} 10531$; $\mathrm{P}_{2}$-BPT-5204; RB-Resistance bulk; SB-susceptible bulk. 
for phenotypically complex traits viz sheath blight and can be particularly useful for mapping genes whose phenotypes cannot be easily separated into discrete classes.

\section{In silico analysis for presence of defense responsive candidate genes within the identified QTLs}

In order to navigate for the presence of candidate defense responsive genes present in the chromosomal regions associated with sheath blight resistance, a search was done in silico using rice data base RAP-DB. This in silico search was done for the presence of defense responsive genes as well as genes associated with signal transduction of biotic stresses.

The search identified in silico a single copy of a hypothetical $\beta$ 1-3 glucanase gene using rice database RAPDB within the identified QTL qshb9.2 associated with RM205 on chromosome 9. A total of 32 genes were predicted within QTL region near to the marker RM205 on chromosome 9 (Table 4). Functional annotation of predicted genes by blastp revealed 1 defense responsive gene $\beta$ 1-3 glucanase like protein present in a single copy within the cluster and it may be responsible for sheath blight resistance in the rice line ARC-10531.

Table 4 List of candidate genes identified in the QTL mapped region qShb 9.2

\begin{tabular}{|c|c|c|c|}
\hline Chr. ID & Locus ID & Position start - end (bp) & Description (RAP-DB annotation) \\
\hline \multirow[t]{32}{*}{ Chr\# 9} & Os09g0520550 & $21076561-21079025$ & Hypothetical protein. \\
\hline & Os09g0522000 & $21137921-21138817$ & Similar to CBF-like protein \\
\hline & Os09g0525300 & $21354401-21357048$ & $\begin{array}{l}\text { Cyclin-like F-box domain } \\
\text { containing protein }\end{array}$ \\
\hline & Os09g0527900 & $21478060-21481626$ & Similar to Hd1-like protein \\
\hline & Os09g0528700 & $21523011-21524758$ & Cytochrome P450 family protein \\
\hline & Os09g0530800 & 21626098- 21629408 & Proteinase inhibitor, propeptide domain containing protein \\
\hline & Os09g0533200 & $21770245-21771297$ & Similar to $\beta$-1, 3-glucanase precursor (EC 3.2.1.39). \\
\hline & Os09g0534600 & 21844366- 21849310 & Similar to Heat shock protein 82 \\
\hline & Os09g0534800 & $21860615-21863638$ & Transcription initiation factor IIB (TFIIB). \\
\hline & Os09g0535200 & $21877935-21881669$ & Conserved Hypothetical protein. \\
\hline & Os09g0535400 & $21886226-21887515$ & Curculin-like (mannose-binding) lectin domain containing protein. \\
\hline & Os09g0536000 & $21895656-21900367$ & Exodeoxyribonuclease III xth family protein. \\
\hline & Os09g0537700 & $21987605-21989587$ & Ribonuclease $\mathrm{T} 2$ family protein \\
\hline & Os09g0538450 & $22028070-22028968$ & Hypothetical protein. \\
\hline & Os09g0540800 & $22123789-22125783$ & Eukaryotic transcription factor, DNA-binding domain containing protein \\
\hline & Os09g0541000 & $22141777-22143042$ & Similar to Plasma membrane intrinsic protein (Aquaporin). \\
\hline & Os09g0541900 & $22170483-22173850$ & Similar to 265 proteasome subunit RPN3a. \\
\hline & Os09g0543900 & $22282226-22284281$ & Transferase family protein. \\
\hline & Os09g0544400 & $22328257-22346493$ & Similar to Glutathione S-transferase GST 16 (EC 2.5.1.18). \\
\hline & Os09g0544900 & $22369643-22374563$ & Glucose/ribitol dehydrogenase family protein. \\
\hline & Os09g0547800 & $22484690-22486975$ & Cyclin-like F-box domain containing protein. \\
\hline & Os09g0549700 & $22577011-22578446$ & Ribosomal protein L18P/L5E family protein. \\
\hline & Os09g0551000 & $22629301-22632936$ & Protein kinase domain containing protein. \\
\hline & Os09g0553100 & $22743724-22744310$ & Histone H4. \\
\hline & Os09g0553600 & $22762665-22766553$ & Similar to NADC homolog. \\
\hline & Os09g0560200 & $23092024-23093755$ & Similar to $26 \mathrm{~S}$ protease regulatory subunit $6 \mathrm{~B}$ \\
\hline & Os09g0562400 & $23166029-23177080$ & Similar to mutator-like transposase [Oryza sativa (japonica cultivar- group)]. \\
\hline & Os09g0563300 & $23214566-23218631$ & $\begin{array}{l}\text { Similar to RuBisCO subunit binding-protein alpha subunit, chloroplast precursor } \\
\text { (60 kDa chaperonin alpha subunit) }\end{array}$ \\
\hline & Os09g0565400 & $23345149-23348841$ & Lipoprotein, type 6 family protein \\
\hline & Os09g0569200 & $23544922-23548178$ & Similar to Beta-amylase (EC 3.2.1.2) (1,4-alpha-D-glucan maltohydrolase). \\
\hline & Os09g0569300 & $23548388-23551570$ & Similar to Calmodulin-binding heat-shock protein \\
\hline & Os09g0569400 & $23551978-23559137$ & Beta-lactamase-like domain containing protein \\
\hline
\end{tabular}


Zuo et al. (2014) reported 12 candidates within the QTL region $q S B-9^{T Q}$ responsible for transferase family proteins glutathione S-transferase and kinase protein. Silva et al. (2012) identified four candidate genes within the major QTL qShB9-2, mapped by Liu et al. (2009). In their study, they found the pathogenesis-related (PR) protein glucan endo-1, 3- $\beta$-glucosidase (glucanase) at two loci on chromosomes 8 and 9. Interestingly in our study also, same kind of gene ( $\beta-1,3$ glucanase like protein) with single copy spanning $21770245 . .21771297 \mathrm{bp}$ was identified on chromosome 9 within the QTL qshb9.2 linked with marker RM205. A wealth of scientific reports (Sridevi et al. 2003; Kalpana et al. 2006) accumulated on plant $\beta-1,3-$ glucanases has enabled us to understand their structure, regulation of expression and the multitude of roles they play directly and indirectly in plants. $\beta$-1, 3-glucanases are most studied with respect to their expression during pathogen infection and their broad spectrum anti-fungal, antimicrobial activity (Ignacimuthu and Antony 2012). Channamallikarjuna et al. (2010) predicted 11 tandem repeats of chitinase genes near the QTL qSBR11-1 on chromosome 11 may be responsible for sheath blight resistance in rice line Tetep. Our study revealed, $\beta-1$, 3-glucanase precursor (EC 3.2.1.39) a PR protein within QTL (qshb9.2) on chromosome 9. Hence, pyramiding of these two major QTLs into one background gives the possibility of combined effect of chitinase and $\beta$-1, 3-glucanase may be the feasible strategy to produce resistant cultivar against ShB.

\section{Conclusion}

In present study two SSR markers namely, RM336 and RM205 were found to be closely associated with the major QTLs qshb7.3 and qshb9.2, respectively in the newly identified source ARC10531 and same were confirmed as well in $\mathrm{BC}_{1} \mathrm{~F}_{2}$ population by bulk segregant analysis approach. The presence of defense responsive gene $\beta$ 1-3 glucanase as well as genes associated with signal transduction of biotic stresses within ShB resistance QTL (qshb9.2) may be responsible for sheath blight resistance in rice line ARC10531. Further, the approach of pyramiding QTLs identified in this source with earlier identified diverse QTLs for ShB resistance may help in developing cultivars with enhanced and durable resistance to this disease.

\section{Additional file}

Additional file 1: Table S1. Standard Evaluation System (SES*) scale (0-9) for Sheath Blight disease scoring *IRRI 2002. Table S2. List of Polymorphic SSR Markers with their details.

\section{Competing interests}

The authors declare that they have no competing interests.

\section{Authors' contributions}

SY carried out all aspects of the experiment and preparation of final draft of the manuscript. GA, LVR, BM and EAS designed the framework of this research, and made suggestions for revision of the draft prepared by SY: RRK contributed in genotyping: RS, KD helped in phenotyping of rice germplasm and mapping population: DV, YKN and FJ contributed reagents/materials and helped in writing manuscript. All authors read and approved the final manuscript.

\section{Acknowledgement}

The authors wish to thank the Director, Institute of Biotechnology, Acharya N.G. Ranga Agricultural University, Hyderabad-500 030, India for providing all the facilities to carry out this present work. The ICAR-SRF fellowship received by SHAILESH YADAV is gratefully acknowledged.

\section{Author details}

${ }^{1}$ Institute of Biotechnology, Acharya N G Ranga Agricultural University, Hyderabad 500030, India. '2Seed Research and Technology Centre, Rajendranagar, Hyderabad 500030, India. ${ }^{3}$ Divison of Plant Pathology, Directorate of Rice Research, Rajendranagar, Hyderabad 500030, India. ${ }^{4}$ International Rice Research Institute, DAPO Box 7777, Metro Manila, Philippines. ${ }^{5}$ Department of Molecular Biology and Genetic Engineering, BAU, Sabour 813210, India.

Received: 24 December 2014 Accepted: 30 March 2015

Published online: 11 April 2015

\section{References}

Ali ML, Pathan MS, Zhang J, Bai G, Sarkarung S, Nguyen HT (2000) Mapping QTLs for root traits in a recombinant inbred population from two indica ecotype in rice. Theor Appl Genet 101:756-766

Bhaktavatsalam G, Satyanarayana K, Reddy PK, John VT (1978) Evaluation of sheath blight resistance in rice. Int Rice Res Newsl 3:9-10

Basten CJ, Zeng SB, Weir BS (2002) QTL Cartographer: A reference manual and tutorial for QTL mapping. Department of Statistics, North Carolina State University, Raleigh, North Carolina, USA

Channamallikarjuna V, Sonah H, Prasad M, Rao GN, Singh NK, Sharma TR (2010) Identification of major quantitative trait loci qSBR ${ }^{11-1}$ for sheath blight resistance in rice. Mol Breed 25:155-166

Churchill GA, Doerge RW (1994) Empirical threshold values for quantitative trait mapping. Genetics 138:963-971

Che KP, Zhan QC, Xing QH, He DJ, Wang B (2003) Tagging and mapping of rice sheath blight resistant gene. Theor Appl Genet 106:293-297

Collard BCY, Jahufer MZZ, Brouwer JB, Pang EK (2005) An introduction to markers, quantitative trait loci (QTL) mapping and marker assisted selection for crop improvement: the basic concepts. Euphytica 142:169-196

Datta K, Velazhahan R, Oliva N, Ona I, Mew T, Khush GS, Muthukrishnan S, Datta SK (1999) Over expression of the cloned rice thaumatin like protein (PR-5) gene in transgenic rice plants enhances environmental friendly resistance to Rhizoctonia solani causing sheath blight disease. Theor Appl Genet 98:1138-1145

Datta K, Tu J, Oliva N, Ona I, Velazhahan R, Mew T, Muthukrishnan S, Datta SK (2001) Enhanced resistance to sheath blight by constitutive expression of infection-related rice chitinase in transgenic elite indica rice cultivars. Plant Sci 160:405-414

Eizenga GC, Prasad B, Jackson AK, Jia MH (2013) Identification of rice sheath blight and blast quantitative trait loci in two different O. sativa/O. nivara advanced backcross populations. Mol Breed 31(4):889-907

Gomez SM, Manikanda BN, Kumar S, Ramasubramanian T, Zhu C, Jeyaprakash P, Senthil A, Chandra Babu R (2010) Molecular mapping and location of QTLS for drought-resistance traits in indica rice (Oryza sativa L.) lines adapted to target environments. Acta Physiol Plant 32:355-364

Han PY, Xing ZY, Chen XZ, Gu LS, Pan BX, Chen LX, Zhang FQ (2002) Mapping QTLs for horizontal resistance to sheath blight in an elite rice restorer line, Minghui 63. Acta Gen Sin 29(4):622-626

Ignacimuthu S, Antony CS (2012) Development of transgenic finger millet (Eleusine coracana(L.) Gaertn.) resistant to leaf blast disease. Jou of Biosci $37: 135-147$ 
IRRI (2002) Standard evaluation system for rice. International Rice Research Institute, Los Banos, Manila, Philippines

Jia Y, Liu GJ, Costanzo S, Lee SH, Dai YT (2009) Current progress on genetic interactions of rice with rice blast and sheath blight fungi. Front Agri in China 3:231-239

Jia L, Yan W, Zhu C, Agrama HA, Jackson A (2012) Allelic analysis of sheath blight resistance with association mapping in Rice. Plos One 7(3):e32703, doi:10.1371/journal.pone.0032703

Kalpana K, Maruthasalam S, Rajesh T, Poovannan K, Kumar KK, Kokiladevi E, Raja JAJ, Sudhakar D (2006) Engineering sheath blight resistance in elite indica rice cultivars using genes encoding defense proteins. Plant Sci 170:203-215

Kosambi DD (1944) The estimation of map distance from recombination values. Ann Eugen 12:172-175

Kunihiro Y, Qian Q, Sato H, Teng S, Zeng DL, Fujimoto K, Zhu LH (2002) QTL analysis of sheath blight resistance in rice (Oryza sativa L). Acta Gen Sin 29:5-15

Lander ES, Green P, Abrahamson J, Barlow A, Daly MJ (1987) MAPMAKER: an interactive computer package for constructing primary genetic linkage maps of experimental and natural populations. Genomics 1:174-81

Li ZK, Pinson SRM, Marshetti MA, Stansel JW, Park WD (1995) Characterization of quantitative trait loci in cultivated rice contributing to field resistance to sheath blight(Rhizoctonia solani). Theor Appl Genet 91:374-381

Lin W, Anuratha CS, Datta K, Potrykus I, Datta S, Muthukrishnan SK (1995) Genetic engineering of rice for resistance to sheath blight. Biotech 13:686-691

Liu G, Jia Y, McClung KM, Datta A, Correll JC (2009) Mapping quantitative trait loci responsible for resistance to sheath blight in rice. Phytopath 99:1078-1084

Liu G, Jia Y, McClung A, Oard JH, Lee FN, Correll JC (2013) Confirming QTLs and finding additional loci responsible for resistance to rice sheath blight disease. Plant Disease 97:113-117

Liu Y, Chen L, Fu D, Lou Q, Mei H, Xiong L, Li M, Xu X, Mei X, Luo L (2014) Dissection of additive, epistatic effect and QTL environment interaction of quantitative trait loci for sheath blight resistance in rice. Hereditas 151:28-37

McCouch SR, Kochert G, Yu ZH, Wang ZY, Khush GS (1988) Molecular mapping of rice chromosomes. Theor Appl Genet 76:815-829

Michelmore R, Paran I, Kesseli RV (1991) Identification of markers linked to disease resistance genes by bulked segregant analysis: a rapid method to detect markers in specific genomic regions by using segregating populations. Proc Natl Acad Sci USA 88:9828-9832

Murray MG, Thompson WF (1980) Rapid isolation of high molecular weight plant DNA. Nucleic Acids Res 8:4321-4325

Pan XB, Rush MC, Sha Y, Xie QJ, Linscombe SD, Stetina SR, Oard JH (1999) Major gene, nonallelic sheath blight resistance from the rice cultivars Jasmine 85 and Teqing. Crop Sci 39:338-346

Pinson SRM, Capdevielle FM, Oard JH (2005) Confirming QTLs and finding additional loci conditioning sheath blight resistance in rice using recombinant inbred lines. Crop Sci 45:503-510

Poland JA, Balint-Kurti PJ, Wisser RJ, Pratt RC, Nelson RJ (2009) Shades of gray: the world of quantitative disease resistance. Trends in PI Sci 14:21-29

Prasad B, Eizenga GC (2008) Rice sheath blight disease resistance identified in Oryza spp. accessions. Plant Disease 92:1503-1509

Price AH, Tomos AD (1997) Genetic dissection of root growth in rice Mapping quantitative trait loci using molecular markers. Theor Appl Genet 95:143-152

Ram T, Majumdar ND, Laha GS, Ansari MM, Kar CS, Mishra B (2008) Identification of donors for sheath blight resistance in wild rice. Indian J of Gen 68:317-319

Sato HI, Deta O, Audo J, Kunihiro Y, Hirabayashi H, Iwano M, Imbe T (2004) Mapping QTLs for sheath blight resistance in the rice line WSS2. Breed SCi $54: 265-271$

Savary S, Castilla N, Elazegui FA, McLaren CG, Ynalvez MA, Teng PS (1995) Direct and indirect effects of nitrogen supply and disease source structure on rice sheath blight spread. Phytopath 85:959-965

Sha XY, Zhu LH (1989) Resistance of some rice varieties to sheath blight (ShB). Int Rice Res Newsl 15:7-8

Sharma A, McClung AM, Pinson SRM, Kepiro JL, Shank AR, Tabien RE, Fjellstrom R (2009) Genetic mapping of sheath blight resistance QTL within tropical japonica rice cultivars. Crop Sci 49:256-264

Shiobara F, Ozaki H, Sato H, Kojima Y, Masahiro M (2013) Mapping and validation of QTLs for rice sheath blight resistance. Breed Sci 63:301-308

Silva J, Scheffler B, Sanabria Y, Guzman C, Galam D, Farmer A, Woodward J, May G, Oard J (2012) Identification of candidate genes in rice for resistance to sheath blight disease by whole genome sequencing. Theor Appl Genet 124:63-74
Singha KD, Borah P (2000) Screening of local upland cultivars of Assam against sheath blight. Ann Bio 16:161-162

Slaton NA, Cartwright R, Meng J, Gbur EE, Norman RJ (2002) Sheath blight severity and rice yield as affected by nitrogen fertilizer rate, application method, and fungicide. Agronomy J 95:1489-1496

Sridevi GN, Sabapathi P, Meena R, Nandakumar T, Samiyappan R, Muthukrishnan S, Veluthambi K (2003) Transgenic indica rice variety Pusa Basmati 1 constitutively expressing a rice chitinase gene exhibits enhanced resistance to Rhizoctonia solani. J Plant Biochem Biotechnol 12:93-101

Srinivasachary WL, Savary S (2011) Resistance to rice sheath blight (Rhizoctonia solani ) disease: current status and perspectives. Euphytica 178:1-22

Subashri M, Robin S, Vinod KK, Rajeswari S, Mohanasundaram K, Raveendran TS (2009) Trait identification and QTL validation for reproductive stage drought resistance in rice using selective genotyping of near flowering RILs. Euphytica 166:291-305

Tan CX, Ji XM, Yang Y, Pan XY, Chen ZX, Zhu LH, Pan XB (2005) Identification and marker-assisted selection of two major quantitative genes controlling rice sheath blight resistance in backcross generations. Acta Gen Sin 32(4):399-405

Teng PS, Torries CQ, Nuque FL, Calvero SB (1990) Current knowledge on crop losses in tropical rice. In: IRRI (ed) Crop loss assessment in rice. International Rice Research Institute, Los Banos, pp 39-54

Vanloon LC, Strien EA (1999) The families of pathogenesis-related proteins, their activities and comparative analysis of PR-1 type proteins. Physiol Mol Plant Path 55:85-97

Wamishe YA, Jia Y, Singh P, Cartwright RD (2007) Identification of field isolates of Rhizoctonia solani to detect quantitative resistance in rice under greenhouse conditions. Front Agric China 1:61-367

Wang S, Basten CJ, Zeng Z (2004) Window QTL Cartographer V 20. Program in Statistical Genetics North Carolina State University, North Carolina, http:// statgen.ncsu.edu/qtlcart/WQTLCart.htm

Wang Y, Pinson SRM, Fjellstrom RG, Tabien RE (2012) Phenotypic gain from introgression of two QTL, aSB9-2 and qSB12-1 for rice sheath blight resistance. Mol Breeding 30:293-303

Willocquet L, Fernandez L, Savary S (2000) Effect of various crop establishment methods practiced by Asian farmers on epidemics of rice sheath blight caused by Rhizoctonia solani. Plant Path 49:346-354

Xu Q, Yuan XP, Yu HY, Wang Y, Tang SX, Wei XH (2011) Mapping quantitative trait loci for sheath blight resistance in rice using double haploid population. Plant Breed 130:404-406

Yin YJ, Zuo SM, Wang H, Chen ZX, Gu SL, Zhang YF, Pan XB (2010) Evaluation of the effect of qSB-9(Tq) involved in quantitative resistance to rice sheath blight using near-iso genic lines. Canadian J of PI Sci 4:731-737

Young ND (1996) QTL mapping and quantitative disease resistance in plants. Ann Rev Phytopath 34:479-501

Zou JH, Pan XB, Hen JY, Xu JF, Lu WX, Zhu LH (2000) Mapping quantitative trait loci controlling sheath blight resistance in two rice cultivars (Oryza sativa L.) Theor Appl Genet 101:569-573

Zuo SM, Yin YJ, Zhang L, Zhang YF, Chen ZX, Pan XB (2007) Breeding value and further mapping of a QTL qSB-11 conferring the rice sheath blight resistance. Chinese J Rice Sci 21:136-142 (in Chinese with English abstract)

Zuo SM, Zhang YF, Chen ZX, Chen XJ, Pan XB (2010) Current progress on genetics and breeding in resistance to rice sheath blight. Scientia Sin Vitae 40:1014-1023

Zuo SM, Yin YJ, Zhang L, Zhang YF, Chen ZX, Pan XB (2013) Fine mapping of qSB-11LE, the QTL that confers partial resistance on rice sheath blight. Theor Appl Genet 126:1257-1272

Zuo SM, ZhuYJ YYJ, Wang H, Zhang YF, Chen ZX, Gu SL, Pan XB (2014) Fine-mapping of qSB-9TQ, a gene conferring major quantitative resistance to rice sheath blight. Mol Breeding 34:2191-2203 